\title{
Clinical, Molecular and Geographical Features of Hereditary Breast/Ovarian Cancer in Latvia
}

\author{
Andris Gardovskis', Arvids Irmejs', Edvins Miklasevics', Viktors Borosenko', Marianna Bitina', Inga Melbarde-Gorkusa', \\ Andrejs Vanags', Grzegorz Kurzawski², Janina Suchy', Bohdan Górski', Janis Gardovskis'
}

1Hereditary Cancer Institute, Riga Stradins University, Latvia; 2International Hereditary Cancer Center, Pomeranian Medical University, Poland

Key words: hereditary, breast/ovarian cancer

Corresponding author: Andris Gardovskis, Hereditary Cancer Institute of Riga Stradins University, Dzirciema str. 16, LV 1007, Riga, Latvia, phone+3719171604; fax+3717069973,e-mail: hci@stradini.lv

Submitted: 11 April 2005

Accepted: 28 April 2005

\begin{abstract}
Introduction. The aim of the study is to evaluate the incidence and phenotype-genotype characteristics of hereditary breast and ovarian cancer syndromes in Latvia in order to develop the basis of clinical management for patients and their relatives affected by this syndrome.

Material and methods. In 2002-2004 in two Latvian oncology hospitals (Liepãja Oncology Hospital and Daugavpils Oncology Hospital) cancer family histories were collected from 287 consecutive patients with breast and ovarian cancer. In all cases, when it was possible to obtain the blood sample, DNA testing for founder mutations in the BRCA1 gene was performed.

Results. Among 287 family cancer histories analysed in 8 (2.8\%) cases criteria of hereditary breast cancer (HBC) were fulfilled and in 5 (1.7\%) cases hereditary breast and ovarian cancer (HBOC) was diagnosed. In 50 (17.4\%) cases we have suspicion of hereditary breast cancer (HBC susp.) and in 8 (2.8\%) cases - suspicion of hereditary breast and ovarian cancer (HBOC susp.). We have one (0.3\%) case with hereditary ovarian cancer (HOC). DNA testing of founder mutations in the BRCA1 gene (exon 20 (5382 insC) exon 5 (300T/G), exon 1 1, 17 (4153delA)) for $178 / 287$ (62\%) patients was performed. In 9/287 (4.9\%) cases we found a mutation in the BRCA1 gene. 4 mutations were detected in exon 11, 17 (4153delA) and 4 mutations in exon 20 (5382 insC) and 1 in exon 5. Conclusions. Existing pedigree/clinical data suggest that in Latvia the clinical frequency of hereditary breast and ovarian cancer is around $5 \%$ of consecutive breast and ovarian cancer patients and suspicion of the syndrome is observed in another $20 \%$ of cases. Frequency of BRCA 1 founder mutations is $5 \%$ of all consecutive breast and ovarian cancers. Considerable geographical differences in the clinical and molecular frequency of hereditary breast ovarian cancer have been observed in Latvia.
\end{abstract}

\section{Introduction}

The annual worldwide incidence of breast cancer is approximately 1,151,300 cases and its worldwide mortality incidence is approximately 410,700 cases [globocan].
The breast cancer is the most frequent cancer among women in Latvia. There are approximately 900 new breast cancer cases diagnosed every year in Latvia and there were 916 new cases detected in 2003. Breast cancer mortality in Latvia was 421 cases in 2002 [Cancer Patient Registry of Latvia, 2004]. Only 65.5\% have been 
Table 1. Age distribution in groups for breast cancer

\begin{tabular}{|c|c|c|c|c|c|c|c|c|}
\hline \multirow[t]{3}{*}{ Decade } & \multicolumn{4}{|c|}{ Study group } & \multicolumn{4}{|c|}{ CPRL group } \\
\hline & \multirow[t]{2}{*}{ Count } & \multirow[t]{2}{*}{$\%$} & \multicolumn{2}{|c|}{$95 \% \mathrm{Cl}$ limits } & \multirow[t]{2}{*}{ Count } & \multirow[t]{2}{*}{$\%$} & \multicolumn{2}{|c|}{$95 \% \mathrm{Cl}$ limits } \\
\hline & & & Lower & Upper & & & Lower & Upper \\
\hline $30-39$ & 13 & $5.2 \%$ & $3.1 \%$ & $8.7 \%$ & 27 & $2.9 \%$ & $2.0 \%$ & $4.1 \%$ \\
\hline $40-49$ & 53 & $21.1 \%$ & $16.6 \%$ & $26.7 \%$ & 167 & $17.6 \%$ & $15.3 \%$ & $20.2 \%$ \\
\hline $50-59$ & 64 & $25.6 \%$ & $20.6 \%$ & $31.4 \%$ & 205 & $21.6 \%$ & $19.1 \%$ & $24.4 \%$ \\
\hline $60-69$ & 66 & $26.4 \%$ & $21.3 \%$ & $32.2 \%$ & 279 & $29.5 \%$ & $26.6 \%$ & $32.4 \%$ \\
\hline $70-79$ & 46 & $18.4 \%$ & $14.1 \%$ & $23.7 \%$ & 207 & $21.9 \%$ & $19.3 \%$ & $24.6 \%$ \\
\hline $80-89$ & 8 & $3.2 \%$ & $1.6 \%$ & $6.2 \%$ & 62 & $6.5 \%$ & $5.1 \%$ & $8.3 \%$ \\
\hline Total & 250 & & & & 947 & & & \\
\hline
\end{tabular}

diagnosed in stage I and II. Another $34.5 \%$ of cases have been diagnosed in stage III and IV, in which treatment is complicated, expensive and results are very often unsatisfactory. 5 -year survival rate for breast cancer in Latvia for stage I disease is $94 \%$, stage II $-78.9 \%$, stage III $-45.4 \%$, stage IV $-6.1 \%$. Overall 5 -year survival rate is $63.2 \%$ [Cancer Patient Registry of Latvia, 2004].

The annual worldwide incidence of ovarian cancer is approximately 204,500 cases and its worldwide mortality incidence is approximately 124,860 cases.

According to the data of the Latvian register of cancer patients in 2003 there were 290 ovarian cancer cases detected. Ovarian cancer mortality in Latvia was 190 cases in 2003. The majority of breast and ovarian cancers are considered as sporadic and development of these cancers has many risk factors. The most frequent factors are woman's age above 50 years and unfavourable reproductive history [1]. Approximately $15-20 \%$ of all breast and ovarian cancers are hereditary $[1,2,3]$. Incidence of hereditary breast/ovarian cancer may vary considerably among different populations and ethnic groups. In the last decades mutations in the BRCA1 and BRCA2 genes responsible for development of hereditary breast and ovarian cancer have been discovered. These cancers result from a strong genetic predisposition and susceptibility in these families is inherited in an autosomal dominant fashion. For women with a mutation in the BRCA1 or BRCA2 gene a lifetime risk of development of breast cancer ranges from $45 \%$ to $85 \%$ and for ovarian cancer the risk ranges from $15 \%$ to $45 \%[2,5]$. Mutation carriers have a slightly increased risk of development of other cancers. Therefore families with hereditary breast and ovarian cancer are in a group with a very high cancer risk, and it is very important to identify these families and take appropriate preventative actions.
The aim of the work is to study clinical and molecular features of hereditary breast and ovarian cancer in Latvia as well to evaluate ethnic and geographical differences in different regions of Latvia.

\section{Material and methods}

During the prospective study from January 2002 to September 2004 cancer family history was collected from 287 consecutive hospital based patients. There were 251 breast cancer and 36 ovarian cancer cases from two oncology hospitals of Latvia (Oncology Hospital of Liepãja, Oncology Hospital of Daugavpils). Liepãja is located in the western part of Latvia while Daugavpils - in the eastern part of Latvia with considerable ethnic differences between those two regions.

Cases were considered as consecutive, if at least $70 \%$ of newly diagnosed patients were involved in the study from a particular hospital in a given period of time. In the consecutive group 128 cases were from the Oncology Hospital of Daugavpils and 159 cases from the Oncology Hospital of Liepãja.

In the study group 284/287 were females and $3 / 287$ - males. For age distribution in groups for breast cancer cases see Table 1. For age distribution in groups for ovarian cancer cases see Table 2.

In the study group with breast cancer for 120/251 cases the stage of cancer was known. Distribution according to cancer stage was as follows: 21 (17.5\%) cases of breast cancer were diagnosed in stage $\mathrm{I} ; 48$ $(40 \%)$ - in stage II; 42 (35\%) - in stage III and 9 (7.5\%) - in stage IV.

In order to evaluate the representativity of the consecutive group, it was compared to all newly diagnosed breast and ovarian cancer cases detected 
Table 2. Age distribution in groups for ovarian cancer

\begin{tabular}{|c|c|c|c|c|c|c|c|c|}
\hline \multirow[t]{3}{*}{ Decade } & \multicolumn{4}{|c|}{ Study group } & \multicolumn{4}{|c|}{ CPRL group } \\
\hline & \multirow[t]{2}{*}{ Count } & \multirow[t]{2}{*}{$\%$} & \multicolumn{2}{|c|}{$95 \% \mathrm{Cl}$ limits } & \multirow[t]{2}{*}{ Count } & \multirow[t]{2}{*}{$\%$} & \multicolumn{2}{|c|}{$95 \% \mathrm{Cl}$ limits } \\
\hline & & & Lower & Upper & & & Lower & Upper \\
\hline $40-49$ & 6 & $16.2 \%$ & $7.7 \%$ & $31.1 \%$ & 47 & $17.4 \%$ & $13.4 \%$ & $22.4 \%$ \\
\hline $50-59$ & 12 & $32.4 \%$ & $19.6 \%$ & $48.5 \%$ & 63 & $23.3 \%$ & $18.7 \%$ & $28.7 \%$ \\
\hline $60-69$ & 13 & $35.1 \%$ & $21.8 \%$ & $51.2 \%$ & 71 & $26.3 \%$ & $21.4 \%$ & $31.9 \%$ \\
\hline $70-79$ & 5 & $13.5 \%$ & $5.9 \%$ & $28.0 \%$ & 66 & $24.4 \%$ & $19.7 \%$ & $29.9 \%$ \\
\hline $80-89$ & 1 & $2.7 \%$ & $0.5 \%$ & $13.8 \%$ & 23 & $8.5 \%$ & $5.7 \%$ & $12.5 \%$ \\
\hline Total & 37 & & & & 270 & & & \\
\hline
\end{tabular}

in 2002-2003 in Latvia. According to data of the Cancer Patients Registry of Latvia (CPRL) during those 2 years (2002-2003) there were 1,865 new breast cancer cases and 579 new ovarian cancer cases diagnosed in Latvia. To compare both groups according to distribution of age at cancer diagnosis Wilson method was used. Since confidence intervals (CI) in all decade groups are overlapping, distribution of age in both groups is the same, if $p=0.05$.

All patients filled in the questionnaire where the following questions were asked: Had your relatives (father, mother, grandparents, siblings, children, grandchildren, aunts, uncles) any tumour? What was the localization of the tumour? At what age was the tumour detected? In all individuals, where blood samples were possible to be obtained, $10 \mathrm{ml}$ of venous blood was taken and molecular testing for founder mutations in the BRCAl gene (exon 20 (5382 insC) exon 5 (300T/G), exon 11, 17 (4153delA) was performed, after written informed consent was obtained from each patient $[6,7]$. For diagnostic criteria for hereditary breast and ovarian cancer syndromes (Hereditary breast cancer (HBC), Hereditary breast/ovarian cancer (HBOC), Hereditary ovarian cancer (HOC)) see Table 3.

The Ethics Commission of Riga Stradins University accepted the protocol for the study.

\section{Results}

Among 287 family cancer histories analyzed in 8/287 (2.8\%) cases criteria of hereditary breast cancer (HBC) were fulfilled and in 5/287 (1.7\%) cases hereditary breast and ovarian cancer ( $\mathrm{HBOC}$ ) was diagnosed.

In 50/287 (17.4\%) cases we have suspicion of hereditary breast cancer (HBC susp.) 25/50 (50\%) of those cases matched criteria of HBC susp. 1 and 25/50 (50\%) cases matched diagnostic criteria of HBC susp. 2. In $8 / 287(2.8 \%)$ cases suspicion of hereditary breast and ovarian cancer (HBOC susp.) was observed. We have $1 / 287(0.3 \%)$ case of hereditary ovarian cancer (HOC). In 30/287 (10\%) families we discovered

Table 3. Clinical diagnostic criteria for hereditary breast and ovarian cancer

\begin{tabular}{|c|c|c|}
\hline $\begin{array}{l}\text { HBC suspected (susp.) } 1 \\
\text { HBOC susp. } 1\end{array}$ & $\begin{array}{l}\text { HBC susp. } 2 \\
\text { HBOC susp. } 2\end{array}$ & $\begin{array}{l}\mathrm{HBC} \\
\mathrm{HBOC}\end{array}$ \\
\hline $\begin{array}{l}\text { One-case families } \\
\text { - at least one of the following } \\
\text { criteria has to be met: }\end{array}$ & $\begin{array}{l}\text { Two-case families } \\
\text { - one of the following criteria has to be met: }\end{array}$ & Three-case families \\
\hline $\begin{array}{l}\text { a) breast cancer diagnosed under the age of } 40 \\
\text { b) medullary or atypical medullary breast cancer } \\
\text { c) male breast cancer } \\
\text { d) breast and ovarian cancer } \\
\text { in the same individual at any age } \\
\text { e) bilateral breast cancer, one of them } \\
\text { diagnosed under the age of } 50\end{array}$ & $\begin{array}{l}\text { a) two breast or two ovarian cancers among } \\
\text { first degree relatives (or second through male) } \\
\text { at any age } \\
\text { b) one breast cancer diagnosed under the age } \\
\text { of } 50 \text { and one ovarian cancer diagnosed } \\
\text { at any age among first degree relatives } \\
\text { (or second through male relatives) }\end{array}$ & $\begin{array}{l}\text { At least three breast or ovarian } \\
\text { cancer patients on the same side } \\
\text { of family diagnosed at any age; } \\
\text { one of those patients is first } \\
\text { degree relative (or second } \\
\text { through male relative } \\
\text { to other two) }\end{array}$ \\
\hline
\end{tabular}


Table 4. Division of mutations in clinical groups

\begin{tabular}{lcccc}
\hline Diagnostic criteria & All cases & Examined cases & Number of BRCA1 mutation & Frequency of mutation \\
\hline HBC & 8 & 7 & 4 & $12.5 \%$ \\
\hline HBOC & 5 & 31 & 3 & $60.0 \%$ \\
\hline HBC susp. & 50 & 6 & 2 & 0 \\
\hline HBOC susp. & 8 & 1 & 0 & $25.0 \%$ \\
\hline HOC susp. & 2 & 1 & 0 & $0 \%$ \\
\hline 2 Br, 1<50 & 1 & 21 & $0 \%$ \\
\hline CFA & 28 & 107 & 0 & $0 \%$ \\
\hline Others & 185 & 178 & 9 & $0 \%$ \\
\hline Total & 287 & & $0 \%$ \\
\hline
\end{tabular}

cancer familial aggregation (at least 3 first degree blood relatives have cancer of any localization).

Currently DNA testing of the BRCAl gene (exon 20 (5382 insC) exon 5 (300T/G), exon 11, 17 (4153delA)) for 178/287 (62\%) patients was performed. In 9/287 (4.9\%) cases we found a mutation in the BRCAl gene. 4 mutations were detected in exon 11, 17 (4153delA) and 4 mutations in exon 20 (5382 ins C) and 1 in exon 5. One mutation was found in the HBC group. The mutation detection rate in the group is $1 / 8$ (12.5\%). 3 mutations were found in the $\mathrm{HBOC}$ group with a mutation detection rate of $3 / 5(60 \%) .3$ mutations were detected in the HBC susp. group with a mutation detection rate of $3 / 50(6 \%)$ and 2 mutations were found in the HBOC susp. group with a mutation detection rate of $2 / 8(25 \%)$. The overall founder mutation detection rate in $\mathrm{HBC}, \mathrm{HBOC}$ and $\mathrm{HBOC}$ susp. clinical groups is $6 / 23(26 \%)$ which underscores the importance of family cancer history and clinical diagnostic criteria in the detection of hereditary breast/ovarian cancer families. For summary of results see Table 4 .

Table 5. Ethnic differences in the regions of Liepãja and Daugavpils

\begin{tabular}{lcc}
\hline Nationality & Region of Daugavpils & Region of Liepãja \\
\hline Latvians & $22.3 \%$ & $62.4 \%$ \\
\hline Russians & $50.6 \%$ & $24.2 \%$ \\
\hline Byelorussians & $8.2 \%$ & $2.9 \%$ \\
\hline Polish & $14.1 \%$ & $0.96 \%$ \\
\hline Jewish & $0.44 \%$ & $0.16 \%$ \\
\hline $\begin{array}{l}\text { Total number } \\
\text { of all nationalities }\end{array}$ & 158,023 & 136,265 \\
\hline
\end{tabular}

For all of the families with definitive or suspected hereditary cancer diagnosis appropriate recommendations concerning prophylactic measures, surveillance and treatment were elaborated on and transmitted in written form.

\section{Discussion}

The overall clinical frequency of definitive hereditary breast/ovarian cancer in our study is $5 \%$ and it is similar to results obtained in the studies from other populations across Europe. Also the frequency of clinically suspected hereditary breast/ovarian cancer is similar to the results from other geographical areas. The overall frequency of three BRCAl founder mutations at a level of $4.9 \%$ confirms earlier data about the presence of a very strong BRCAl founder effect in Latvia shared with Poland, Lithuania, Byelorussia and to a smaller extent also other East European populations.

However the most interesting finding is considerable differences of features of hereditary breast/ovarian cancer between two historically, geographically and ethnically different regions of Latvia, the region of Liepãja and that of Daugavpils. The distance between those two regions is approximately $500 \mathrm{~km}$. A map of Latvia with both regions marked is presented in Fig. 1 . For ethnic differences in the regions of Liepãja and Daugavpils see Table 5. Among 287 family cancer histories analysed, 128 cases come from the Oncology Hospital of Daugavpils and 159 cases from the Oncology Hospital of Liepãja. From all 8 (2.8\%) cases of hereditary breast cancer (HBC), 7 cases come from the Oncology Hospital of Daugavpils and only one case from the Oncology Hospital of Liepãja. Among hereditary breast and ovarian cancer cases (HBOC) 
Table 6. Comparison between regions of Liepãja and Daugarpils

\begin{tabular}{lcccc}
\hline Diagnostic criteria & Number of cases in Liepãja & BRCA1 mutations & Number of cases in Daugavpils & BRCA1 mutations \\
\hline HBC & $1(0.63 \%)$ & 0 & $7(5.5 \%)$ & 1 \\
\hline HBOC & $0(0 \%)$ & 0 & $5(3.9 \%)$ & 3 \\
\hline HBC susp. 1 & $8(5 \%)$ & 0 & $17(13.2 \%)$ & 2 \\
\hline HBC susp. 2 & $8(5 \%)$ & 0 & $17(13.2 \%)$ & 1 \\
\hline HBOC susp. & $3(1.9 \%)$ & 1 & $1(0.78 \%)$ & 1 \\
\hline HOC susp. & $1(0.63 \%)$ & $1(0.6 \%)$ & 128 & $8(6.3 \%)$ \\
\hline Total & 159 & & 0 & 0 \\
\hline
\end{tabular}

all 5 (1.7\%) cases come from the Oncology Hospital of Daugavpils. 8 BRCAl founder mutations were detected in the region of Daugarpils and only one in the region of Liepãja, resulting in BRCAl founder mutation frequency in consecutive breast and ovarian cancers of $6.3 \%$ and $0.6 \%$, respectively. Table 6 presents a comparison of clinical and molecular results between regions of Liepãja and Daugavpils.

According to those first results we can presume that in the region of Daugavpils there could be threefold to tenfold higher clinical and molecular frequency of hereditary breast cancer (HBC) and hereditary breast and ovarian cancer (HBOC). Due to this finding of increased frequency of hereditary breast and ovarian cancer, the region of Daugavpils and other south eastern neighbouring regions of Latvia could be considered as regions of the highest risk, where systematic government funded hereditary breast and ovarian cancer screening program should be started due to limited finances in the healthcare system.

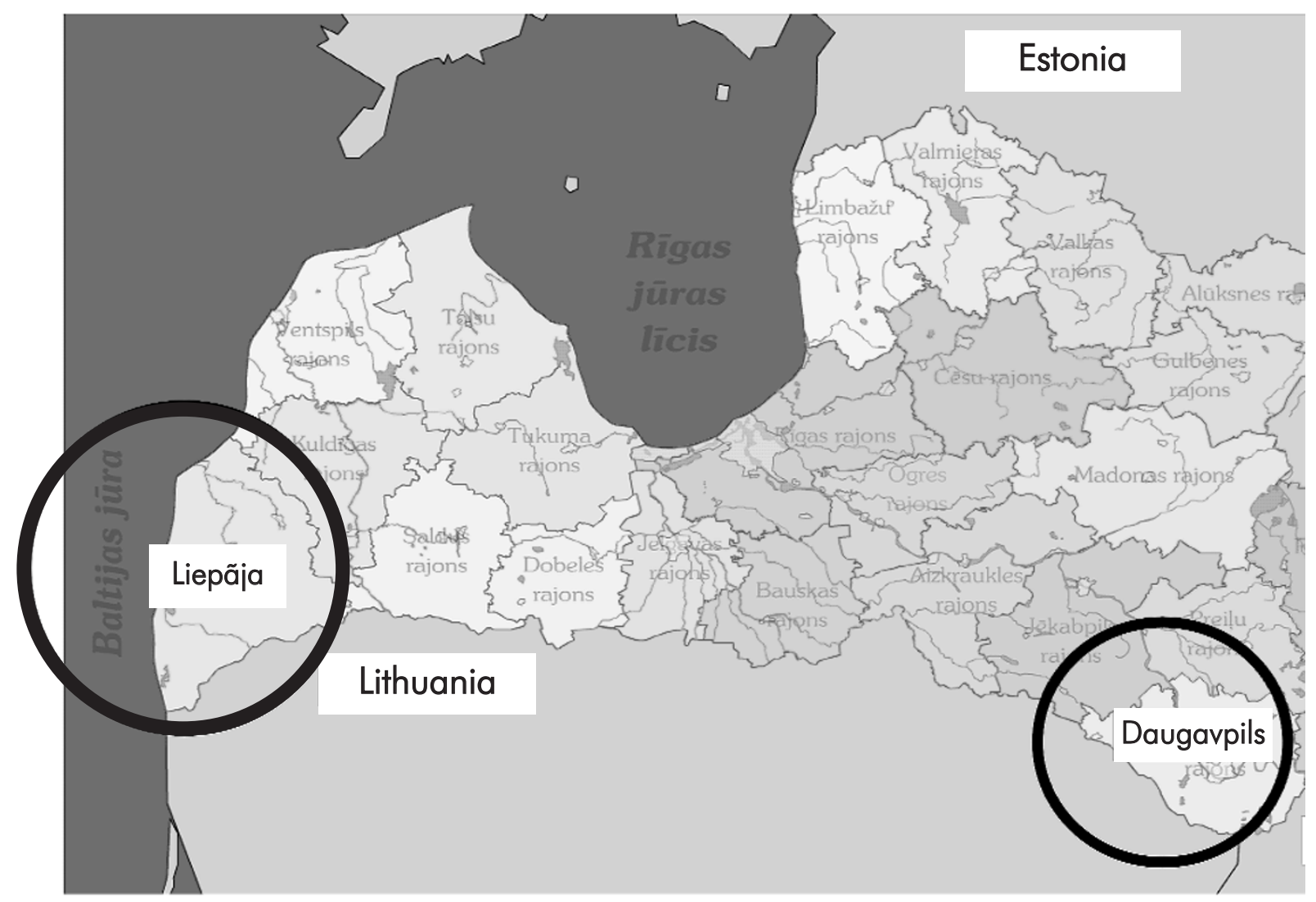

Fig. 1. Geographical map of Latvia 
One of probable explanations for this very considerable difference in clinical and molecular frequency of hereditary breast/ovarian cancer between regions of Daugavpils and Liepãja is related to ethnic features, especially a considerably larger number of Polish, Byelorussian and Jewish inhabitants as well historical Polish, Byelorussian and Jewish influence in the region of Daugavpils. A very strong founder effect of BRCAl mutations as well as high frequency of hereditary breast ovarian cancer in the population of Poland and high frequency of BRCA1 mutations in Ashkenazi Jewish population are well known.

In spite of this very obvious finding, it is difficult to draw definitive conclusions because there is room for several potential biases. Firstly, the number of examined cases is small and further collection of cases is necessary to confirm the results with statistical significance. Secondly, Latvia is a small country and probably some selected patients from the regions of Daugavpils and Liepãja underwent their cancer treatment in oncology hospitals of Riga. Thirdly, no patients from two largest oncology hospitals located in Riga were involved in the study and this could influence the overall rate of frequency of clinical and molecular features observed in our study.

\section{Conclusions}

Existing pedigree/clinical data suggest that the overall clinical frequency of hereditary breast and ovarian cancer in Latvia is around $5 \%$ of consecutive breast and ovarian cancer patients and suspicion of the syndrome is observed in another $20 \%$ of cases. Frequency of BRCA 1 founder mutations is $5 \%$ of all consecutive breast and ovarian cancers. Considerable geographical differences in the clinical and molecular frequency of hereditary breast ovarian cancer have been observed in Latvia. However the number of patients involved in the study is not sufficient and more patients have to be studied to confirm the results.

\section{References}

1. Jacobi CE, Jonker MA, Nagelkerke NJD, van Houwelingen JC and de Bock GH. Prevalence of family histories of breast cancer in the general population and the incidence of related seeking of health care. J Med Genet 2003; 40: e83.

2. Hereditair Mamma (Ovarium) Carcinoom. In: Erfelijke tumoren. Richtlijnen voor diagnostiek en preventie. Stichting Opsporing Erfelijke Tumoren\&Vereniging Klinische Genetica Nederland, Werkgroep Klinische Oncogenetica 2001; 7-13.

3. Ford D, Easton DF, Stratton M, Narod S, Goldgar D, Devilee P, Bishop DT, Weber B, Lenoir G, Chang-Claude J, Sobol H, Teare MD, Struewing J, Arason A, Scherneck S, Peto J, Rebbeck TR, Tonin P, Neuhausen S, Barkardottir R, Eyfjord J, Lynch H, Ponder
BA, Gayther SA, Zelada-Hedman M, et al. Genetic heterogeneity and penetrance analysis of the BRCA1 and BRCA2 genes in breast cancer families. Am J Hum Genet 1998; 62: 676-689.

4. Levine DA and Gemignani ML. Prophylactic surgery in hereditary breast/ovarian cancer syndrome. Oncology 2003; 17 (7): 932-952.

5. Antoniou A, Pharoah PD, Narod S, Risch HA, Eyfjord JE, Hopper $\mathrm{JL}$, Loman N, Olsson H, Johannsson O, Borg A, Pasini B, Radice P, Manoukian S, Eccles DM, Tang N, Olah E, Anton-Culver H, Warner E, Lubinski J, Gronwald J, Gorski B, Tulinius H, Thorlacius S, Eerola H, Nevanlinna H, Syrjakoski K, Kallioniemi OP, Thompson D, Evans C, Peto J, Lalloo F, Evans DG and Easton DF. Average risks of breast and ovarian cancer associated with BRCA1 or BRCA2 mutations detected in case Series unselected for family history: a combined analysis of 22 studies. Am J Hum Genet 2003; 72 (5): $1117-1130$.

6. McPherson K, Steel CM and Dixon JM. ABC of breast diseases. Breast cancer-epidemiology, risk factors, and genetics. BMJ 2000; 321 : 624-628.

7. Csokay B, Tihomirova L, Stengrevics A, Sinicka $O$ and Olah E. Strong founder effects in BRCA 1 mutation carrier breast cancer patients from Latvia. Mutation in brief no. 258. Hum Mutat 1999; 14 (1): 92.

8. Moller P, Borg A, Evans DG, Haites N, Reis MM, Vasen H, Anderson E, Steel CM, Apold J, Goudie D, Howell A, Lalloo F, Maehle L, Gregory H and Heimdal K. Survival in prospectively ascertained familial breast cancer: analysis of a series stratified by tumour characteristics, BRCA mutations and oophorectomy. Int J Cancer 2002; 101 (6): 555-559.

9. Meijers-Heijboer $H$, Brekelmans CT, Menke-Pluymers $M$, Seynaeve C, Baalbergen A, Burger C, Crepin E, van den Ouweland AW, van Geel B and Klijn JG. Use of genetic testing and prophylactic mastectomy and oophorectomy in women with breast or ovarian cancer from families with a BRCA1 or BRCA2 mutation. J Clin Oncol 2003; 21 (9): 1675-1681.

10. Zeigler LD and Kroll SS. Primary breast cancer after prophylactic mastectomy. Am J Clin Oncol 1991; 14: 451-453.

11. Bergthorsson JT, Ejlertsen B, Olsen JH, Borg A, Nielsen KV, Barkardottir RB, Klausen S, Mouridsen HT, Winther K, Fenger K, Niebuhr A, Harboe TL and Niebuhr E. BRCA1 and BRCA2 mutation status and cancer family history of Danish women affected with multifocal or bilateral breast cancer at a young age. J Med Genet 2001; 38 (6): 361-368.

12. Rebbeck TR, Lynch HT, Neuhausen SL, Narod SA, Van'† Veer L, Garber JE, Evans G, Isaacs C, Daly MB, Matloff E, Olopade OI, Weber BL; Prevention and Observation of Surgical End Points Study Group. Prophylactic oophorectomy in carriers of BRCA1 or BRCA2 mutations. N Engl J Med 2002; 346 (21): 1616-1622.

13. Narod SA, Dube MP, Klijn J, Lubinski J, Lynch HT, Ghadirian P, Provencher D, Heimdal K, Moller P, Robson M, Offit K, Isaacs C, Weber B, Friedman E, Gershoni-Baruch R, Rennert G, Pasini B, Wagner T, Daly M, Garber JE, Neuhausen SL, Ainsworth P, Olsson H, Evans G, Osborne M, Couch F, Foulkes WD, Warner E, Kim-Sing C, Olopade O, Tung N, Saal HM, Weitzel J, Merajver S, Gauthier-Villars M, Jernstrom H, Sun P and Brunet JS. Oral contraceptives and the risk of breast cancer in BRCA1 and BRCA2 mutation carriers. J Natl Cancer Inst 2002; 94 (23): 1773-1779.

14. Narod SA, Brunet JS, Ghadirian P, Robson M, Heimdal K, Neuhausen SL, Stoppa-Lyonnet D, Lerman C, Pasini B, de los Rios P, Weber B, Lynch H; Hereditary Breast Cancer Clinical Study Group. Tamoxifen and risk of contralateral breast cancer in BRCA1 and BRCA2 mutation carriers: a case-control study. Hereditary Breast Cancer Clinical Study Group. Lancet 2000; 356: 1876-1881. 